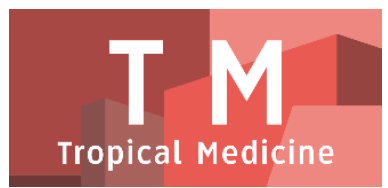

PAPER - OPEN ACCESS

\title{
Uji Efek Kombinasi Amoksisilin Dengan Ekstrak Etanol Daun Sirih (Piper Betle L) Terhadap Pertumbuhan Bakteri Escherichia Coli Dan Staphylococcus Aureus
}

\author{
Author : Panal Sitorus \\ DOI $\quad: 10.32734 /$ tm.v1i1.67 \\ Paper Page : 313 - 319
}

Volume 1 Issue 1 - 2018 TALENTA Conference Series: Tropical Medicine (TM)

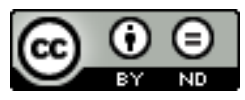

This work is licensed under a Creative Commons Attribution-NoDerivatives 4.0 International License.

Published under licence by TALENTA Publisher, Universitas Sumatera Utara
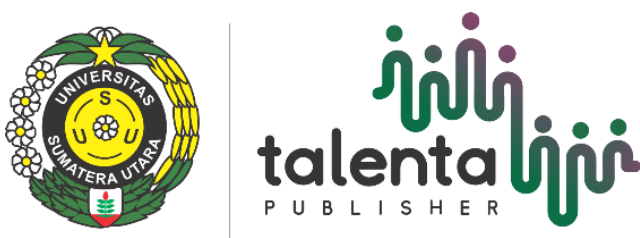


\title{
Uji Efek Kombinasi Amoksisilin Dengan Ekstrak Etanol Daun Sirih (Piper Betle L) Terhadap Pertumbuhan Bakteri Escherichia Coli Dan Staphylococcus Aureus
}

\author{
Dr. Panal Sitorus, M.Si,. Apt ${ }^{\mathrm{a}}$ \\ ${ }^{a}$ Fakultas Farmasi, Universitas Sumatera Utara 20155, Indonesia \\ sitoruspanal@gmail.com
}

\begin{abstract}
Abstrak
Latar belakang: Konsep baru untuk pengobatan infeksi bakteri resisten adalah dengan kombinasi antibiotika dengan ekstrak herbal. Ekstrak daun sirih memiliki aktivitas anti bakteri terhadap Escherichia coli dan Staphylococcus aureus kerena daun sirih mengandung metabolit sekunder. Kombinasi ekstrak daun sirih dengan amoksisilin, perlu diuji untuk mengetahui efek antibaktreri masing-masing dibandingkan dengan kombinasinya

Tujuan Penelitian: Mengetahui karakteristik dan skrining fitokimia simplisia dan ekstrak daun sirih serta uji aktivitas anti bakteri kombinasi amoksisilin dengan ekstrak daun sirih terhadap Escherichia coli dan Staphylococcus aureus.

Metode Penelitian: Penelitian ini meliputi ekstraksi serbuk simplisia dengan maserasi, Karakterisasi simplisia untuk mengetahui kadar air, kadar sari larut dalam air, kadar sari larut dalam etanol, kadar abu total dan kadar abu tidak larur asam, serta skrining fitokimia simplisia dan ekstrak daun sirih serta uji aktivitas anti bakteri kombinasi amoksisilin dengan ekstrak daun sirih terhadap Escherichia coli dan Staphylococcus aureus dengan metode difusi agar menggunakan cakram kertas,

Hasil Penelitian: Hasil penelitian menunjukkan bahwa serbuk simplisia daun sirih memiliki kadar air 3,66\%; , kadar sari larut dalam air 22,54\%, kadar sari larut dalam etanol 14,65\%, kadar abu total9,25\% dan kadar abu tidak larur asam 1,03\%. Komponen kimia pada simplisia dan ekstrak etanol serbuk daun sirih adalah flavonoid, tannin, saponin dan steroid. Ekstrak etanol serbuk daun sirih menghambat pertumbuhan bakteri Escherichia coli dan Staphylococcus aureus masing-masing pada KHM $8 \mathrm{mg} / \mathrm{ml}$ dan $9 \mathrm{mg} / \mathrm{ml}$. Amoksisilin menghambat pertumbuhan bakteri Escherichia coli dan Staphylococcus aureus masing-masing pada KHM $5 \mathrm{~g} / \mathrm{ml}$ dan $10 \mathrm{~g} / \mathrm{ml}$ dengan diameter zona hambat 6,83mm dan 7,05 mm. Diameter zona hambat terhadap Escherichia coli dan Staphylococcus aureus meningkat ketika bakteri uji dipaparkan dengan kombinasi ekstrak etanol daun sirih dengan amoksisilin.
\end{abstract}

Kesimpulan: Dari hasil penelitian menunjukkan bahwa kombinasi Amoksisilin dengan Ekstrak etanol daun sirih menunjukkan efek yang sinergis

Kata Kunci: Antibakteri, kombinasi, KHM, amoksisilin, daun sirih, Escherichia coli, Staphylococcus aureus;

\section{Pendahuluan}

Amoksisilin adalah antibiotik golongan penisilin berspektrum luas, rentan terhadap enzim penisilinase, yaitu suatu $\beta$-laktamase yang mampu memecah cincin $\beta$-Laktam pada penisilin sehingga penisilin tidak efektif (Carranza dan Takei, 2011). Beberapa penelitian menunjukkan bahwa amoksisilin telah resisten terhadap beberapa kuman 
patogen seperti E. coli Pseudomonas sp, Klebsiella sp, St. epidermidis dan St. aureus mempunyai resistensi tinggi terhadap amoksisilin (Refdanita, dkk., 2004)

Upaya untuk menanggulangi resistensi bakteri terhadap amoksisislin adalah dengan

mengembangkan antibakteri baru dari bahan alam (Islam, et al,. 2011). Tanaman obat kaya akan berbagai metabolit sekunder yang berkhasiat sebagai antimikroba (Abdallah, 2011).

Sirih salah satu tanaman yang banyak digunakan masyarakat secara tradisional sebagai obat infeksi dan dapat dikembangkan sebagai sumber antibiotik baru. Daun sirih memiliki aktivitas antibakteri (Pradhan, et al., 2013; Subashkumar, et al., 2013; Bangash, et al., 2012; Khan, et al., 2011). Daun sirih mengandung metabolit sekunder seperti tanin, flavonoid dan minyak atsiri (Baskaran, et al.,

2011). senyawa tersebut mampu menghambat pertumbuhan bakteri E. coli dan St. aureus, bakteri tersebut menghasilkan enterotoksin yang dapat menyebabkan diare. Sirih mengandung minyak atsiri, tanin dan flavonoid yang memiliki aktivitas antimikroba dengan cara mendenaturasi protein dan

merusak dinding sel bakteri, serta merusak lipid pada membran sel melalui mekanisme penurunan tegangan permukaan membran sel. (Pelezar dan chan, 2008),

Salah satu pendekatan baru untuk pengobatan penyakit infeksi bakteri dan mengatasi resistensi bakteri adalah penggunaan ekstrak tanaman, baik dalam bentuk tunggal maupun kombinasi dengan antibiotika (Chanda dan Rakholiya, 2011). Penggunaan kombinasi dua anti bakteri adalah alternatif yang baik untuk mencegah terjadinya resistensi bakteri terhadap antibiotik tertentu (Joung, et al., 2012). Kombinasi antibiotik dan ekstrak tanaman merupakan konsep baru dan telah digunakan untuk pengobatan infeksi bakteri resisten. Kombinasi dapat berupa ekstrak tanaman yang berbeda atau ekstrak tanaman dengan antibiotik standar (Chanda dan Rakholiya, 2011).

Berdasarkan uraian di atas maka peneliti melakukan pengujian efek kombinasi ekstrak etanol

96\% daun sirih (Piper betle L) dengan amoksisilin terhadap pertumbuhan bakteri Escherichia coli dan

Staphylococcus aureus.

\section{Metode Penelitian}

\subsection{Pembuatan Ekstrak Etanol Daun Sirih (EEDS)}

Sebanyak 600 g serbuk simplisia dimaserasi dengan $4500 \mathrm{ml}$ etanol $96 \%$ selama 5 hari terlindung dari cahaya, kemudian campuran diserkai. Ampas dicuci dengan etanol 96\%, Maserat didiamkan di tempat terlindung dari cahaya selama 2 hari, kemudian disaring, diuapkan dengan menggunakan rotary evaporator pada temperatur $\pm 40^{\circ} \mathrm{C}$ sampai diperoleh ekstrak kental, kemudian diuapkan dengan penangas air sampai diperoleh ekstrak kental (Ditjen POM., 1979).

\subsection{Pemeriksaan Karakteristik Simplisia}

Pemeriksaan karakteristik simplisia meliputi pemeriksaan makroskopik, mikroskopik, penetapan kadar air, penetapan kadar sari larut air, penetapan kadar sari larut etanol, penetapan kadar abu total dan penetapan kadar abu tidak larut asam (Depkes RI, 2005).

\subsection{Skrining fitokimia Serbuk Simplisia dan Ekstrak}

Skrining fitokimia serbuk simplisia dan ekstrak daun sirih dilakukan untuk menganalisis senyawa golongan kimia yang terkandung pada simplisia dan ekstrak daun sirih. Depkes (1979) dan Farnsworth (1966)

\subsection{Pembuatan Larutan Uji Ekstrak Etanol Daun Sirih (EEDS)}

Ekstrak ditimbang $100 \mathrm{mg}$ dan dilarutkan dengan DMSO hingga $10 \mathrm{ml}$ (konsentrasi ekstrak $10 \mathrm{mg} / \mathrm{ml}$ ) 
larutan tersebut diencerkan hingga diperoleh ekstrak dengan konsentrasi 9; 8; 7; 6;5; 4;3;2;1 mg/ml, kemudian dimasukkan cakram kertas kedalam ekstrak dengan berbagai konsentrasi diatas, di diamkan 30 menit.

\subsection{Pembuatan Larutan Uji Amoksisilin}

Amoksisilin ditimbang $10 \mathrm{mg}$ dilarutkan dengan DMSO hingga $10 \mathrm{ml}$ maka konsentrasi amoksisilin $1000 \mu \mathrm{g} / \mathrm{ml}$ kemudian diambil $0,1 \mathrm{ml}$ dengan menggunakan pipet mikro dimasukkan kedalam vial, dicukupkan dengan $10 \mathrm{ml}$ DMSO hingga diperoleh konsentrasi amoksisilin $10 \mu \mathrm{g} / \mathrm{ml}$ kemudian dibuat pengenceran selanjutnya sampai diperoleh amoksisilin dengan konsentrasi $9 ; 8 ; 7 ; 6 ; 5 ; 4 ; 3 ; 2 ; 1 \mu \mathrm{g} / \mathrm{ml}$, kemudian dimasukkan cakram kertas kedalam amoksisilin dengan berbagai konsentrasi, diamkan 30 menit.

\subsection{Pembuatan Larutan Uji Kombinasi EEDS Dengan Amoksisilin}

Timbang EEDS $200 \mathrm{mg}$ dilarutkan dengan DMSO hingga $10 \mathrm{ml}$ maka konsentrasi ekstrak etanol daun sirih 20 $\mathrm{mg} / \mathrm{ml}$ kemudian dibuat pengenceran selanjutnya sampai diperoleh ekstrak etanol dengan konsentrasi 16;12; 8; 4 $\mathrm{mg} / \mathrm{ml}$. Ditimbang $20 \mathrm{mg}$ amoksisilin dilarutkan dengan DMSO hingga $10 \mathrm{ml}$ maka konsentrasi amoksisilin 2000 $\mu \mathrm{g} / \mathrm{ml}$ kemudian diambil $0,1 \mathrm{ml}$ dengan menggunakan pipet mikro dimasukkan kedalam vial, dicukupkan dengan $10 \mathrm{ml}$ DMSO hingga diperoleh konsentrasi amoksisilin $20 \mu \mathrm{g} / \mathrm{ml}$ kemudian dibuat pengenceran selanjutnya sampai diperoleh amoksisilin dengan konsentrasi $18 ; 16 ; 12 ; 8 ; 4 \mathrm{mg} / \mathrm{ml}$.

Dipipet masing-masing 0,5 $\mathrm{ml}$ amoksisilin 4; 8; 12; 18; $20 \mu \mathrm{g} / \mathrm{ml}$ dimasukkan kedalam vial lalu ditambahkan 0,5 ml ekstrak etanol daun sirih dengan konsentrasi hambat minimum (KHM). Lalu dilakukan cara yang sama dipipet $0,5 \mathrm{ml}$ ekstrak etanol daun sirih $4 ; 8 ; 12 ; 18 ; 20 \mathrm{mg} / \mathrm{ml}$ dimasukkan kedalam vial lalu ditambahkan $0,5 \mathrm{ml}$ amoksisilin dengan konsentrasi hambat minimum (KHM).

\subsection{Pembuatan inokulum bakteri St. aureus dan E. coli}

Koloni bakteri St. aureus dan E. coli diambil dari stok kultur menggunakan jarum ose steril dan disuspensikan kedalam $10 \mathrm{ml}$ media nutrient broth steril lalu diinkubasikan pada suhu 35 $\pm 20 \mathrm{C}$ sampai didapat kekeruhan dengan transmitan 25\% menggunakan alat spektrofotometer UV panjang gelombang $580 \mathrm{~nm}$ (Ditjen POM., 1995).

\subsection{Pengujian Aktivitas Anti bakteri}

Sebanyak $0,1 \mathrm{ml}$ inokulum dimasukkan ke dalam cawan petri steril, setelah itu dituang media nutrient agar sebanyak $20 \mathrm{ml}$ dengan suhu $45-50^{\circ} \mathrm{C}$, selanjutnya cawan digoyang di atas pemukaan meja agar media dan suspensi bakteri tercampur rata dan dibiarkan memadat. Pada media yang telah padat diletakkan beberapa pencadang kertas yang telah direndam EEDS; Amoksisilin dan kombinasi EEDS dan amoksisilin dengan berbagai konsentrasi, kemudian diinkubasi pada suhu $35 \pm 1{ }^{\circ} \mathrm{C}$ selama $18-24$ jam. Lalu diukur diameter zona hambatan pertumbuhan bakteri di sekitar pencadang dengan menggunakan jangka sorong (Ditjen POM., 1995).

Penentuan aktivitas antibakteri dilakukan dengan metode difusi agar dengan menggunakan media padat dan cakram kertas. Zona hambat pertumbuhan mikroba adalah daerah jernih disekeliling cakram kertas. Pengukuran zona hambat pertumbuhan bakteri dilakukan dengan menggunakan jangka sorong, semakin tinggi konsentrasi ekstrak akan menghasilkan diameter zona hambat yang lebih besar karena semakin banyak zat aktif yang terkandung dalam ekstrak tersebut (Dwidjoseputro, 1998) 


\section{Hasil dan Pembahasan}

\subsection{Rendemen Simplisia dan Ekstrak}

Hasil penyarian $600 \mathrm{~g}$ serbuk simplisia daun sirih dengan pelarut etanol $96 \%$. Maserat diuapkan dengan alat rotary evaporator, dikeringkan dengan penangas air dan ditimbang. Ekstrak kental diperoleh sebanyak 138,39 g. Ekstrak ini digunakan untuk uji golongan senyawa kimia dan uji aktivitas antibakteri terhadap bakteri St. aureus dan E. coli.

Hasil karakterisasi simplisia daun sirih yang diperoleh dapat dilihat pada Tabel 1

Tabel. 1 Hasil pemeriksaan karakterisasi simplisia daun sirih.

\begin{tabular}{|c|l|c|}
\hline No & \multicolumn{1}{|c|}{ Karakteristik } & Hasil \% \\
\hline 1 & Kadar air & 3,66 \\
\hline 2 & Kadar sari larut air & 22.54 \\
\hline 3 & Kadar sari larut etanol & 14,65 \\
\hline 4 & Kadar abu total & 9,25 \\
\hline 5 & Kadar abu tidak larut asam & 1,03 \\
\hline
\end{tabular}

Hasil uji golongan senyawa kimia serbuk simplisia dan EEDS dapat dilihat pada Tabel, 2.

Tabel 2 Hasil uji golongan senyawa kimia dari serbuk simplisia dan EEDS.

\begin{tabular}{|c|c|c|c|}
\hline \multirow{2}{*}{ No } & Metabolit sekunder & \multicolumn{2}{|c|}{ Hasil } \\
\cline { 3 - 4 } & & simplisia & Ekstrak \\
\hline 01 & Alkaloid & - & - \\
\hline 02 & Flavonoid & + & + \\
\hline 03 & Saponin & + & + \\
\hline 04 & Tanin & + & + \\
\hline 05 & Glikosida & + & + \\
\hline 06 & Steroida/triterpenoid & & + \\
\hline
\end{tabular}

Keterangan : (+), (-) = Tidak ada

\subsection{Hasil Pengujian Aktivitas Anti bakteri}

Hasil uji aktivitas antibakteri menunjukkan bahwa EEDS dapat menghambat pertumbuhan bakteri St.aureus pada konsentrasi $100 \mathrm{mg} / \mathrm{ml}$ dengan diameter zona hambat 14,4 mm dan bakteri E.coli pada konsentrasi $100 \mathrm{mg} / \mathrm{ml}$ dengan diameter zona hambat sebesar $14,03 \mathrm{~mm}$. Nilai KHM pada EEDS terhadap bakteri St. aureus pada konsentrasi $9 \mathrm{mg} / \mathrm{ml}$ dengan diameter zona hambat $6,23 \mathrm{~mm}$ dan pada bakteri E. coli pada konsentrasi $8 \mathrm{mg} / \mathrm{ml}$ dengan diameter zona hambat 7,22 $\mathrm{mm}$ dapat dilihat pada Tabel,3.

Tabel 3. Hasil Pengujian Aktivitas Anti bakteri EEDS.

\begin{tabular}{|c|c|c|c|c|c|}
\hline \multirow{2}{*}{ No } & \multirow{2}{*}{$\begin{array}{c}\text { Konsentrasi EEDS } \\
(\mathbf{m g} / \mathrm{ml})\end{array}$} & \multicolumn{4}{|c|}{ Diameter Zona Hambat Pertumbuhan Bakteri (mm)* } \\
\cline { 3 - 7 } & & \multicolumn{3}{|c|}{ St. aureus } & \multicolumn{2}{c|}{ E. coli. } \\
\cline { 3 - 7 } & & $\mathbf{D}^{*}$ & SD & 18.57 & \pm 0.59 \\
\hline 1 & 500 & 18.83 & \pm 0.58 & 17.32 & \pm 1.17 \\
\hline 2 & 400 & 17.43 & \pm 0.60 & & SD \\
\hline
\end{tabular}




\begin{tabular}{|c|c|c|c|c|c|}
\hline 3 & 300 & 16.17 & \pm 0.42 & 16.35 & \pm 1.00 \\
\hline 4 & 200 & 15.27 & \pm 0.42 & 15.50 & \pm 0.60 \\
\hline 5 & 100 & $\mathbf{1 4 . 4}$ & \pm 0.63 & $\mathbf{1 4 . 0 3}$ & \pm 0.86 \\
\hline 6 & 90 & 13.93 & \pm 1.00 & 13.90 & \pm 0.35 \\
\hline 7 & 10 & 7.52 & \pm 0.35 & 8.12 & \pm 0.45 \\
\hline 8 & 9 & $\mathbf{6 . 2 3}$ & \pm 0.16 & 7.62 & \pm 1.14 \\
\hline 9 & 8 & - & - & $\mathbf{7 . 2 2}$ & \pm 0.45 \\
\hline 10 & 7 & - & - & - & - \\
\hline 11 & Blank & - & - & - & - \\
\hline
\end{tabular}

Sirih (Piper betle) memiliki potensi sebagai antibakteri yaitu dengan adanya senyawa-senyawa flavonoida, saponin, tanin yang mempunyai potensi sebagai antibakteri (Robbinson, 1995). Senyawa flavonoida berungsi sebagai antibakteri dengan cara membentuk senyawa kompleks terhadap protein ekstraselluler yang mengganggu intergritas membran sel bakteri. Saponin termasuk dalam kelempok antibakteri yang mengganggu permeabilitas membran sel bakteri, yang mengakibatkan kerusakan membran sel dan menyebabkan keluarnya berbagai komponen penting dari dalam sel bakteri yaitu protein, asam nukleat dan nukleotida. Tanin merupakan senyawa metabolit sekunder pada tanaman yang bersifat sebagai antibakteri, memiliki kemampuan menyamak kulit dan juga dikenal sebagai adstrigensia (Robinson, 1995)

Hasil uji aktivitas antibakteri amoksisilin menunjukkan bahwa Amoksisilin dapat menghambat pertumbuhan bakteri St.aureus pada konsentrasi $1000 \mu \mathrm{g} / \mathrm{ml}$ dengan diameter zona hambat 14,43 $\mathrm{mm}$ dan bakteri E.coli pada konsentrasi $1500 \mu \mathrm{g} / \mathrm{ml}$ dengan diameter zona hambat sebesar 14,08 mm.. Nilai KHM pada Amoksisilin terhadap bakteri St. aureus pada konsentrasi $5 \mu \mathrm{g} / \mathrm{ml}$ dengan diameter zona hambat $6,83 \mathrm{~mm}$ dan pada bakteri E. coli pada konsentrasi $10 \mu \mathrm{g} / \mathrm{ml}$ dengan diameter zona hambat 7,05mm .dapat dilihat pada Tabel,4.

Tabel. 4 Hasil uji aktivitas anti bakteri amoksisilin (A) terhadap St. aureus dan E. coli.

\begin{tabular}{|c|c|c|c|c|c|}
\hline \multirow{3}{*}{ NO } & \multirow{3}{*}{$\begin{array}{l}\text { Konsentrasi } \\
(\mathrm{A})(\mu \mathrm{g} / \mathrm{mL})\end{array}$} & \multicolumn{4}{|c|}{ Diameter Zona Hambat Pertumbuhan Bakteri $(\mathrm{mm})^{*}$} \\
\hline & & \multicolumn{2}{|c|}{ E.coli } & \multicolumn{2}{|c|}{ St.aureus } \\
\hline & & $\mathrm{D}^{*}$ & SD & $\mathrm{D}^{*}$ & SD \\
\hline 1 & 2000 & 15.70 & \pm 0.49 & 14.63 & \pm 0.26 \\
\hline 2 & 1750 & 15.50 & \pm 0.53 & 14.40 & \pm 0.26 \\
\hline 3 & 1500 & 15.35 & \pm 0.56 & 14.08 & \pm 0.28 \\
\hline 4 & 1250 & 14.92 & \pm 0.61 & 13.70 & \pm 0.05 \\
\hline 5 & 1000 & $\mathbf{1 4 . 4 3}$ & \pm 0.34 & 12.98 & \pm 0.15 \\
\hline 6 & 750 & 13.98 & \pm 0.21 & 12.73 & \pm 0.10 \\
\hline 7 & 20 & 10.58 & 0.45 & 8.08 & \pm 0.42 \\
\hline 8 & 10 & 9.25 & 0.26 & 7.05 & \pm 1.14 \\
\hline 9 & 9 & 8.35 & 0.28 & - & - \\
\hline 10 & 5 & 6.83 & 0.25 & - & - \\
\hline 11 & 4 & - & - & - & - \\
\hline 12 & Blanko & - & - & - & - \\
\hline
\end{tabular}

Setelah dilakukan uji aktivitas antibakteri pada masing masing sampel uji dari EEDS dan amoksisilin terhadap bakteri St. aureus dan E. coli kemudian dilakukan kombinasi dari keduanya dan dilakukan uji aktivitas anti bakteri. Parameter yang digunakan untuk melakukan kombinasi adalah nilai KHM, dimana pada uji aktivitas antibakteri EEDS terhadap St. aureus memiliki nilai KHM pada konsentrasi $9 \mathrm{mg} / \mathrm{ml}$ yaitu $6,23 \mathrm{~mm}$ dan nilai KHM terhadap E. coli terdapat pada konsentrasi $8 \mathrm{mg} / \mathrm{ml}$ yaitu $7,22 \mathrm{~mm}$, sedangkan pada uji aktivitas antibakteri amoksisilin 
nilai KHM terhadap bakteri St.aureus yang didapat adalah pada konsentrasi $10 \mu \mathrm{g} / \mathrm{ml}$ dengan diameter zona hambat 7,05 mm dan pada bakteri E. coli diameter zona hambat $6,83 \mathrm{~mm}$ pada konsentrasi $5 \mu \mathrm{g} / \mathrm{ml}$.

Hasil uji aktivitas anti bakteri EEDS kombinasi dengan amoksisilin terhadap bakteri St.aureus dapat dilihat pada Tabel. 5 dan Gambar 1 dan 2.

Tabel.5 Hasil uji aktivitas anti bakteri EEDS kombinasi dengan amoksisilin terhadap bakteri St. aureus

\begin{tabular}{|c|c|c|c|c|c|c|}
\hline \multirow{3}{*}{ NO } & \multirow{3}{*}{$\begin{array}{c}\text { Konsentrasi Kombinasi A } \\
\text { dengan EEDS }\end{array}$} & \multirow{2}{*}{\multicolumn{2}{|c|}{$\begin{array}{c}\begin{array}{c}\text { Diameter Zona } \\
\text { Hambat }\end{array} \\
\text { St. aureus }\end{array}$}} & \multirow{3}{*}{$\begin{array}{c}\text { Konsentrasi Kombinasi EEDS } \\
\text { dengan A }\end{array}$} & \multirow{2}{*}{\multicolumn{2}{|c|}{$\begin{array}{c}\begin{array}{c}\text { Diameter Zona } \\
\text { Hambat }\end{array} \\
\text { St. aureus }\end{array}$}} \\
\hline & & & & & & \\
\hline & & $\mathbf{D}^{*}$ & SD & & $\mathbf{D}^{*}$ & SD \\
\hline 1 & $2 \mu \mathrm{g} / \mathrm{ml}+9 \mathrm{mg} / \mathrm{ml}$ & 8.90 & \pm 0.70 & $2 \mathrm{mg} / \mathrm{ml}+10 \mu \mathrm{g} / \mathrm{ml}$ & 8.00 & \pm 0.80 \\
\hline 2 & $4 \mu \mathrm{g} / \mathrm{ml}+9 \mathrm{mg} / \mathrm{ml}$ & 9.42 & \pm 0.54 & $4 \mathrm{mg} / \mathrm{ml}+10 \mu \mathrm{g} / \mathrm{ml}$ & 8.47 & \pm 0.63 \\
\hline 3 & $6 \mu \mathrm{g} / \mathrm{ml}+9 \mathrm{mg} / \mathrm{ml}$ & 9.95 & \pm 0.42 & $6 \mathrm{mg} / \mathrm{ml}+10 \mu \mathrm{g} / \mathrm{ml}$ & 9.20 & \pm 0.42 \\
\hline 4 & $8 \mu \mathrm{g} / \mathrm{ml}+9 \mathrm{mg} / \mathrm{ml}$ & 10.18 & \pm 0.35 & $8 \mathrm{mg} / \mathrm{ml}+10 \mu \mathrm{g} / \mathrm{ml}$ & 9.57 & \pm 0.30 \\
\hline 5 & $10 \mu \mathrm{g} / \mathrm{ml}+9 \mathrm{mg} / \mathrm{ml}$ & 11.10 & \pm 0.05 & $10 \mathrm{mg} / \mathrm{ml}+10 \mu \mathrm{g} / \mathrm{ml}$ & 10.07 & \pm 0.03 \\
\hline
\end{tabular}

Keterangan: A:Amoksisili

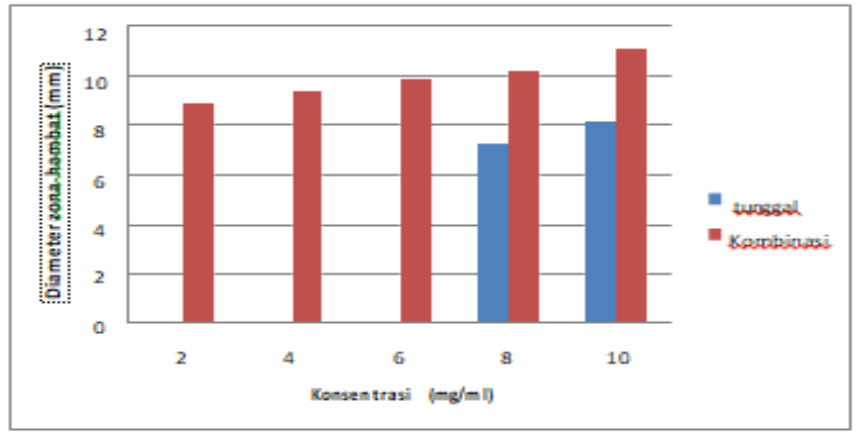

Gambar.1 Grafik perbandingan uji aktivitasanti bakteri kombinasi dari KHM EEDS dengan Amoksisilin terhadav bakteri St. aureus.

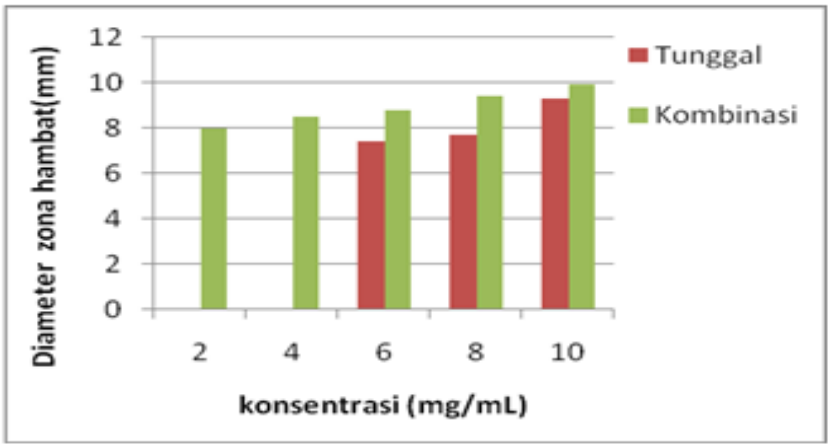

Gambar 2. Grafik perbandingan uji aktivitas anti bakteri kombinasi EEDS dengan KHM Amoksisilin terhadap bakteri $S t$. aureus. 
Hasil uji aktivitas anti bakteri EEDS kombinasi dengan amoksisilin terhadap bakteri E.coli dapat dilihat pada Tabel 6 dan Gambar 3 dan 4

Tabel.6 Hasil uji aktivitas antibakteri EEDS kombinasi dengan amoksisilin terhadap bakteri E. coli

\begin{tabular}{|c|c|c|c|c|c|c|}
\hline \multirow{3}{*}{ NO } & \multirow{3}{*}{$\begin{array}{c}\text { Konsentrasi Kombinasi A } \\
\text { dengan EEDS }\end{array}$} & \multirow{2}{*}{\multicolumn{2}{|c|}{$\begin{array}{c}\begin{array}{c}\text { Diameter Zona } \\
\text { Hambat }\end{array} \\
\text { E. coli }\end{array}$}} & \multirow{3}{*}{$\begin{array}{c}\text { Konsentrasi Kombinasi EEDS } \\
\text { dengan A }\end{array}$} & \multirow{2}{*}{\multicolumn{2}{|c|}{$\begin{array}{c}\begin{array}{c}\text { Diameter Zona } \\
\text { Hambat }\end{array} \\
\text { E. coli }\end{array}$}} \\
\hline & & & & & & \\
\hline & & D* & SD & & $\mathbf{D}^{*}$ & SD \\
\hline 1 & $2 \mu \mathrm{g} / \mathrm{ml}+8 \mathrm{mg} / \mathrm{ml}$ & 8.00 & \pm 0.63 & $2 \mathrm{mg} / \mathrm{ml}+5 \mu \mathrm{g} / \mathrm{ml}$ & 7.97 & \pm 0.63 \\
\hline 2 & $4 \mu \mathrm{g} / \mathrm{ml}+8 \mathrm{mg} / \mathrm{ml}$ & 8.20 & \pm 0.56 & $4 \mathrm{mg} / \mathrm{ml}+5 \mu \mathrm{g} / \mathrm{ml}$ & 8.47 & \pm 0.62 \\
\hline 3 & $6 \mu \mathrm{g} / \mathrm{ml}+8 \mathrm{mg} / \mathrm{ml}$ & 8.52 & \pm 0.45 & $6 \mathrm{mg} / \mathrm{ml}+5 \mu \mathrm{g} / \mathrm{ml}$ & 8.75 & \pm 0.54 \\
\hline 4 & $8 \mu \mathrm{g} / \mathrm{ml}+8 \mathrm{mg} / \mathrm{ml}$ & 9.47 & \pm 0.22 & $8 \mathrm{mg} / \mathrm{ml}+5 \mu \mathrm{g} / \mathrm{ml}$ & 9.38 & \pm 0.37 \\
\hline 5 & $10 \mu \mathrm{g} / \mathrm{ml}+8 \mathrm{mg} / \mathrm{ml}$ & 9.90 & \pm 0.25 & $10 \mathrm{mg} / \mathrm{ml}+5 \mu \mathrm{g} / \mathrm{ml}$ & 10.90 & \pm 0.18 \\
\hline
\end{tabular}

Keterangan : A : Amoksisilin

Gambar. 3 Grafik perbandingan uji aktivitas anti bakteri kombinasi EEDS dengan KHM Amoksisilin terhadap bakteri E. coli.

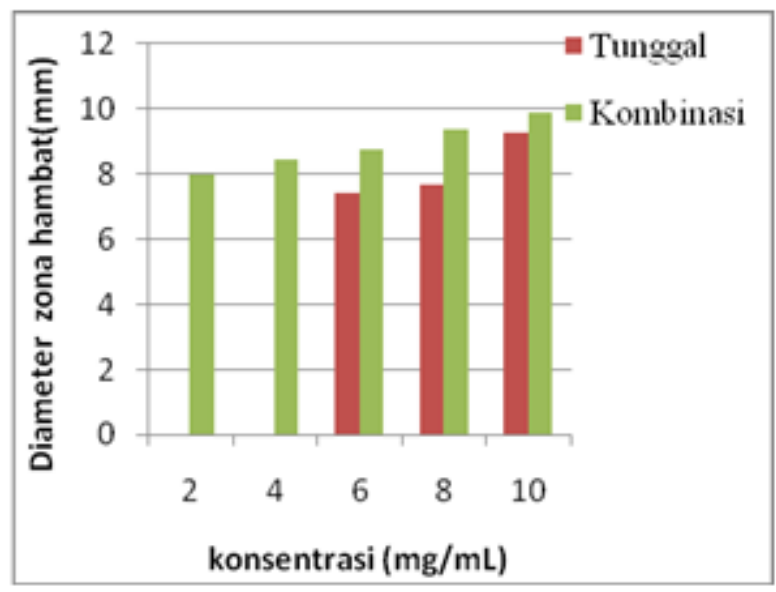

Gambar 4. Grafik perbandingan uji aktivitas antibakteri kombinasi dari KHM EEDS dengan Amoksisilin terhadap bakteri E. coli.

\section{Kesimpulan}

Hasil penelitian menunjukkan bahwa kombinasi ekstrak etanol daun sirih (EEDS) dengan Amoksisilin, KHM sebagai parameter uji, menunjukkan bahwa kombinasi antara ekstrak etanol daun sirih dan amoksisilin dapat menghambat pertumbuhan bakteri St. aureus dan E. coli. dengan efek yang sinergis. 


\section{Daftar Pustaka}

[1] Abdallah, E.M. (2011). Plants: An Alternative Source for Antimicrobials. Journal of Applied Pharmaceutical Science, 01 (06): 18.

[2] Bangash, F.A., Hashmi A.N., Mahboob, A., Zahid, M., Hamid, B., Muhammad S.A., Shah, Z.U., Afzaal, H. (2012). IN-VITRO Antibacterial Activity Of Piper betel Leaf Extracts. 639 | J App Pharm 03(04): 639-646.

[3] Baskaran., Ratha., dan Kanimozhi. (2011). Screening For Antimicrobial Activity And Phytochemical Analysis Of Various Leaf Extract Of Murraya koenigii. IJRAP. Vol. 2(6): 1807-1810.

[4] Chanda, S., dan Rakholiya, K. (2011). Combination therapy: synergism between natural plant Extracts and Antibiotics Against Infectious Diseasses. Hal. 520-529.

[5] Depkes RI. (1995). Materia Medika Indonesia. Jilid VI. Cetakan Keenam. Jakarta: Direktorat Jendral Pengawasan Obat dan Makanan. Hal. 247-251, 199-304, 321-325.

[6] Ditjen POM. (1979). Farmakope Indonesia. Edisi III. Jakarta: Departemen Kesehatan RI. Hal. 9, 33.

[7] Ditjen POM RI. (2005). Penyiapan Simplisia Untuk Sediaan Herbal . Jakarta: Badan Pengawasan Obat dan Makanan Republik Indonesia. Hal. 1.

[8] Ditjen POM. (2000). Parameter Standar Umum Ekstrak Tumbuhan Obat. Jakarta: Departemen Kesehatan RI. Hal. 10-11.

[9] Farnsworth, N.R. (1996). Biological and Phytochemical Screening of Plants, Journal of Pharmaceutical Sciences. Vol. 55. No. 3. Chicago: Reheis Chemical Company. Hal. 262-264.

[10] Islam, M, M., Masum, S., Makbub, K. R., and Haque, M. Z., (2011). Antibacterial Activity of Crab of Amoxicilin Againt Staphylococcus aureus and Eschericia coli. Journal of Advanced Scientific Research. 2(4): 63-66.

[11] Jawetz, E., Melnick, J.L., dan Adelberg, E.A. (2001). Mikrobiologi Kedokteran. Jakarta: Salemba Medika. Hal. 318 - 319.

[12] Khan, A.J., Kumar, N. (2011). Evaluation of Antibacterial Properties of Extracts of Piper betle Lef. Journal of Pharmaceutical and Biomedical Sciences, Vol (11) : 1-3.

[13] Lay, B.W., dan Sugiyo, H. (1994). Analisis Mikroba di Laboratorium. Jakarta: PT. Raja Grafindo Persada. Hal. $34,72-73$.

[14] Pratiwi, S.T. (2008). Mikrobiologi Farmasi. Jakarta: Penerbit Erlangga. Hal.105-117,140-142.

[15] Robinson, T. (1995). Kandungan Organik Tumbuhan Tinggi. Bandung: ITB.

[16] Schwalbe, R., Moore, L, S., and Goodwin, A,C. (2007). Antimicrobial Susceptibility Testing Protocols, USA: CRC Press. Hal. $277,282,283$.

[17] Subashkumar, R., Sureshkumar, M., Babu, S and Tha, T. (2013). Antibacterial effect of crude aqueous extract of Piper betle L. against pathogenic bacteria. International Journal of Research in Pharmaceutical and Biomedical Sciences Vol. 4 (1): 42.

[18] World Health Organization. (2011). Quality Control Methods for Herbal Material. Switzerland: WHO. Hal. 29-38. 